\title{
A New Set of Monoclonal Antibodies Directed to Proline-Rich and Central Regions of p53
}

\author{
T. VOELTZEL, ${ }^{1,5}$ A.-P. MOREL, ${ }^{1}$ M.-C. $\operatorname{ROSTAN},{ }^{1} \mathrm{~J} . \mathrm{JI},{ }^{1}$ C. CHIODINO,${ }^{1}$ F. PONCHEL,${ }^{2}$ J. VIGOUROUX, ${ }^{1}$ \\ CLAUDE CARON DE FROMENTEL,${ }^{1}$ T. SOUSSI, ${ }^{3}$ and M. OZTURK ${ }^{1,4}$
}

\begin{abstract}
The p53 protein can adopt several conformations in cells- "latent," "active," or mutant-depending on cellular stress or mutations of the TP53 gene. Today, only a few antibodies discriminating these conformations are available. We produced three new anti-p53 monoclonal antibodies (MAbs) directed against epitopes of human p53. The H53C1 MAb recognizes an epitope located at the N-terminal part of the central region of p53 and can discriminate mutant from wild-type conformation. The H53C2 and H53C3 MAbs are against different epitopes within the proline-rich region of p53. Moreover, the H53C2 epitope is located in the second negative regulatory domain of p53 between residues 80 and 93 . These MAbs can be used as new tools to study and modulate the cellular functions of p53.
\end{abstract}

\section{INTRODUCTION}

$\mathbf{T}$ P53 IS A TUMOR SUPPRESSOR GENE, which displays structural and functional alterations in more than $50 \%$ of human cancers. ${ }^{(1)}$ The wild-type p53 protein, a transcription factor, is known for its ability to induce growth arrest and/or apoptosis after exposure of cells to stress. After DNA damage, the loss of a functional p53, as in many tumor cells, authorizes cell proliferation or cell survival without repair of DNA lesions, greatly contributing to tumor progression. The cell cycle arresting activity of p53 is mainly mediated by transcriptional activation of $\mathrm{p} 21^{\mathrm{WAF} 1 / \mathrm{cip} 1}$ gene expression. The $\mathrm{p} 21^{\mathrm{WAF} 1 / \mathrm{cip} 1}$ protein inhibits cyclin-dependent kinase 2/cyclin E activity leading to a G1 arrest. ${ }^{(2)}$ p53-dependent apoptosis may be mediated by transcriptional activation of various genes including BAX, but p53 may also induce apoptosis without transcriptional activation. ${ }^{(3-5)}$

Several functional domains have been characterized in the p53 protein. The amino acid residues $1-40$ correspond to the transactivation domain which binds to TFIID. ${ }^{(6,7)}$ The core domain (residues 102-292) is the specific DNA binding domain of p53. It contains four out of the five evolutionary conserved domains of p53 and has been crystallized. ${ }^{(8-10)}$ Most of the p53 gene alterations found in human cancers is missense mutations located in this core region. Three domains are related to the regulation of this transactivation activity. Residues 319-360 correspond to an oligomerization domain necessary for the transcriptional activity. ${ }^{(1)}$ Two domains are involved in the negative regulation of specific DNA binding: one of these regions is located between amino acids 80 and $94,{ }^{(12)}$ the other one is within the C-terminus, between residues 364 and 393.(13,14) Finally, a proline-rich region (residues 63-85) is associated to transcription-independent growth suppression by $\mathrm{p} 53 .^{(15-17)}$

The use of antibodies recognizing specific regions of $\mathrm{p} 53$ greatly helped to characterize the structure/function relationship of the protein. For example, MAbs binding to the core region of p53, such as PAb 240 (epitope 213-217), which can distinguish mutant from wild-type $\mathrm{p} 53$ by immunoprecipitation, contributed to the understanding of the importance of the conformational state $\mathrm{p} 53$ activity. ${ }^{(18-20)}$ The ability of the MAb PAb 421 (epitope 371-380) to activate p53 transcriptional activity demonstrated that the $\mathrm{C}$-terminal region of p53 is a negative regulatory domain. ${ }^{(13,14)}$ The use of scFv derived from the DO1 $\mathrm{MAb}$ revealed the implication of the $\mathrm{N}$-terminal region in the stability of the p53 protein. ${ }^{(21)}$

${ }^{1}$ INSERM U590, Centre Léon Bérard, Lyon, France.

${ }^{2}$ Molecular Medicine Unit, University of Leeds, Leeds, United Kingdom.

${ }^{3}$ Hopital Tenon, Paris, France.

${ }^{4}$ Department of Molecular Biology and Genetics, Faculty of Science, Bilkent University, Ankara, Turkey. 
The core region is hydrophobic and poorly immunogenic. Indeed, most antisera from patients with tumors expressing mutant p53 and most MAbs produced towards the whole protein recognize epitopes located in the $\mathrm{N}$ - and $\mathrm{C}$ - terminal regions of p53. (22) So far, only few MAbs recognizing epitopes located in core region were generated, some of them distinguish potentially active from inactive forms of $\mathrm{p} 53$ by immunoprecipitation. ${ }^{(18-20)}$

In this context, generation of MAbs recognizing epitopes in human p53 core region could help to further characterize the functional properties of different p53 structural domains. Furthermore, until now, only two mAbs have been described that recognize the proline-rich region spanning the residues 64-92; a region shown to be involved in the transmission of anti-proliferative signals ${ }^{(15,16)}$ and in negative regulation of the transcriptional activity of p53 (amino acids 80-93). ${ }^{(12)}$

The aim of this study was to produce new monoclonal antibodies (MAbs), specific for the proline-rich and the DNA binding domains. A truncated recombinant $\mathrm{p} 53$, including residues 72-308, was used as immunogen. Three MAbs were selected. Two of them recognize different motifs in the proline-rich region of $\mathrm{p} 53$. The other one binds the $\mathrm{N}$-terminal part of the core domain and appears to be specific of the p53 conformation.

\section{MATERIALS AND METHODS}

\section{Cell lines}

MCF7, HepG2, HBL100, BT20, T47D, Huh7, Mahlavu, and Hep3B cell lines were from ATCC and maintained as described. ${ }^{(23)}$ The 3B143, 3B248, and 3B249 cell lines were obtained following transfection of Hep3B cells with pC53-143A, pC53-248W, and pC53-249R, respectively, and selection with geneticine. ${ }^{(23)}$

\section{Production of p53-derived fusion proteins}

Recombinant $\mathrm{p} 53$ proteins were produced through the 6-Histidine QIA express system (Qiagene, Coger, France) using pQE 30 and pQE 32 as vectors. RT-PCR produced cDNA fragments corresponding to full size or truncated p53 mRNAs were cloned in frame downstream a 6His-tag between BamH1 and Hind III restriction sites. Expression in E. coli and purification of proteins were carried out following manufacturer's instructions. A truncated p53 protein corresponding to amino acids 72-308 of p53 was produced using pQE30 as vector and named $6 \mathrm{H}-\mathrm{Cp} 53$.

\section{Monoclonal antibodies}

Purified 6His-central P53 protein $(6 \mathrm{H}-\mathrm{Cp} 53)$ was injected into 6-week-old BALB/c mice. Spleen lymphocytes from a hyperimmune animal were fused to SP2/O myeloma in presence of polyethylene glycol. Hybridomas were selected in hypoxanthine/ aminopterin/thymidine medium. Specific antibody secretion was checked by indirect RIA using central (6H-Cp53) and total (6H-p53) p53 6His fused proteins as antigen and ${ }^{125} \mathrm{I}-$ labelled goat anti-mouse immunoglobulins as secondary probe. Hybridomas were cloned by limiting dilution. ${ }^{(24)}$

Commercially available PAb $240^{(25)}$ and PAb1801(26) from Oncoscience (TEBU, France) were used as control antibodies.

\section{Pepscan ELISA analysis}

These analyses have been performed as previously described. ${ }^{(27)}$ Briefly, 77 biotinilated 15 -mer peptides overlapping each other by 10 residues and spanning p53 were produced. Each peptide was deposited in a streptavidin precoated well of microtiter plates. After washing, hybridoma supernatants were incubated and the presence of specific antibodies was revealed using a horseradish peroxydase-coupled sheep secondary antibody and Orthophenylene diamine (OPD).

\section{Immunoprecipitation}

For metabolic labeling, $70 \%$ confluent cells were deprived of serum and methionine for $2 \mathrm{~h}$ prior a 4-h incubation in the presence of $\left[{ }^{35} \mathrm{~S}\right]$-methionine $(200 \mu \mathrm{Ci} / \mathrm{mL})$. Cells were then washed with PBS and lysed in lysis buffer $(50 \mathrm{mM}$ Tris $\mathrm{pH} 7.4$, $25 \mathrm{mM} \mathrm{NaCl}, 1 \mathrm{mM} \mathrm{CaCl}_{2}$, and $50 \mathrm{mM} \mathrm{NaF}$ ) with a cocktail of protease inhibitor (PIC) containing PMSF $(50 \mu \mathrm{g} / \mathrm{mL})$, Leupeptin $(1 \mu \mathrm{g} / \mathrm{mL})$, Soybean Trypsin Inhibitor $(10 \mu \mathrm{g} / \mathrm{mL})$, Aprotinin $(1 \mu \mathrm{g} / \mathrm{mL})$ and TPCK $(10 \mu \mathrm{g} / \mathrm{mL})$ for $20 \mathrm{~min}$ at $4^{\circ} \mathrm{C}$. Cell extracts were then centrifuged for $15 \mathrm{~min}$ at $4^{\circ} \mathrm{C}$ and supernatant pre-cleared $1 \mathrm{~h}$ with protein $\mathrm{A}$. Incubation with specific mAbs was carried out overnight at $4^{\circ} \mathrm{C}$ with gentle shaking. The immune complexes were precipitated with $80 \mu \mathrm{L}$ of Protein A-sepharose beads for 1-h incubation. After four washes with lysis buffer, the immune complexes were separated by SDS-PAGE. Dried gels were exposed to autoradiography.

\section{RESULTS}

In order to obtain mAbs specific for human p53 core and proline-rich regions, a histidine-tagged truncated protein corresponding to amino acids $72-308$ of p53 was produced in $E$. coli. Affinity-purified recombinant p53 protein was then used as immunogen to generate mouse mAbs. Fusion experiments were performed as previously described ${ }^{(24)}$ and hybridoma supernatants tested by solid-phase radioimmunoassay (RIA). As observed by other groups, ${ }^{(19,20)}$ fusion yields were lower than those observed using immunogens containing the N-terminal region of the $\mathrm{p} 53$ protein, as only 25 of 525 hybridoma supernatants displayed strong immunogenicity to the immunogen (data not shown). We performed a further selection by RIA against recombinant full-size and truncated p53 proteins. Supernatants were also tested for their ability to recognize p53 from cells by western-blot and immuno-cytochemistry (Table 1).

After this further selection, six clone supernatants were tested for epitope definition by a PEPSCAN ELISA technique described by Legros et al. ${ }^{(27)}$ As presented in Table 1, the H53C1 MAb recognized five residues from Tyr126 to Leu130. This epitope is located in the core domain within the second highly conserved region of p53, as indicated in Figure 1. Two other $\mathrm{mAbs}$ recognized epitopes in the region flanking the core domain of p53: H53C2, binding p53 between Ala86 and Ser95 and H53C3, between Ala76 and Pro80. As shown in Figure 1, these epitopes are located in the proline-rich region described by Walker and Levine and match different proline (P-X-X-P) motifs. ${ }^{(15)}$ The epitope of $\mathrm{H} 53 \mathrm{C} 2$ also partially covers the negative regulatory domain described by Muller-Tiemann (12). 
Table 1. Characteristics of Antibodies Obtained after Immunization with a Recombinant Truncated p53 Protein (72-308)

\begin{tabular}{|c|c|c|c|c|c|c|}
\hline MAbs & Isotype & Epitope & $\begin{array}{c}\text { ELISA } \\
6 H-C p 53\end{array}$ & $W B$ & $I P$ & IC \\
\hline $\mathrm{H} 53 \mathrm{C} 1$ & IgG1 & 126-YSPAL-130 & ++ & + & + & + \\
\hline $\mathrm{H} 53 \mathrm{C} 2$ & IgG1 & 86-APAPSWPLSS-95 & ++ & ++ & ++ & ++ \\
\hline $\mathrm{H} 53 \mathrm{C} 3$ & IgG1 & 76-APAAP-80 & ++ & $+/-$ & ++ & + \\
\hline $\mathrm{H} 53 \mathrm{C} 4$ & $\operatorname{IgM}$ & 181-RCSDSDGLAP-190 & ++ & ++ & ND & ND \\
\hline $\mathrm{H} 53 \mathrm{C} 8$ & IgG3 & 181-RCSDSDGLAP-190 & + & + & ND & ND \\
\hline $\mathrm{H} 53 \mathrm{C} 9$ & IgG1 & 181-RCSDSDGLAP-190 & + & + & ND & ND \\
\hline
\end{tabular}

Epitopes were determined using PEPSCAN analysis as described by Legros et al. ${ }^{26}$ ELISA was performed on the central part of p53 protein (6H-Cp53). WB (Westen Blot) and IC (ImmunoCytochemistry) were performed on p53 transfected cells.

Three other antibodies $\mathrm{H} 53 \mathrm{C} 4, \mathrm{C} 8$ and C9, recognized an epitope located between Arg181 and Pro190 which is recognized by previously described MAbs. Hybridomas producing antibodies $\mathrm{H} 53 \mathrm{C} 1, \mathrm{H} 53 \mathrm{C} 2$, and $\mathrm{H} 53 \mathrm{C} 3$ were cloned twice by limited dilution and their epitopes confirmed.

In order to determine the specificity of these three MAbs for wild-type and mutant conformations of p53, we performed immunoprecipitations under non-denaturing conditions using extracts from human cell lines expressing either wild-type or mutant p53 proteins. MAb PAb1801 was used as a reference for all conformations and PAb 240 for its specificity towards the mutant form of $\mathrm{p} 53$. Immunoprecipitations performed using the hybridoma $\mathrm{H} 53 \mathrm{C} 1$ cells revealed that it is able to distinguish different conformations of p53 (Fig. 2 and Table 2). Indeed, it precipitated most of the mutant $\mathrm{p} 53$ proteins tested, but not the wild-type form of the protein. These observations suggest that the epitope recognized by $\mathrm{H} 53 \mathrm{C} 1$ is not available for antibody binding in the wild-type conformation. Surprisingly, this antibody recognized three bands in Huh7 cell extracts, but none of them corresponded to the expected size for p53 (Fig. 2).

In contrast to $\mathrm{H} 53 \mathrm{C} 1$, the $\mathrm{H} 53 \mathrm{C} 2 \mathrm{MAb}$ recognizes both wildtype and mutant forms of p53 (Fig. 2 and Table 2). Two other previously described MAbs (HO15-4 and HO16-4) binding the same epitope have been shown to selectively recognize the mutant p53 conformation by immunoprecipitation. ${ }^{(19)}$ The third $\mathrm{MAb}$ (H53C3) could immunoprecipitate all tested forms of p53, although its binding affinity appeared to be weaker than that of $\mathrm{H} 53 \mathrm{C} 2$.

\section{DISCUSSION}

The aim of this study was to produce new MAbs specific for p53 regions for which there is a limited number of available antibodies, namely proline-rich and DNA-binding domains. The amino- and carboxy-terminal regions of p53 are highly immunogenic, and it is not likely to obtain antibodies against the less immunogenic proline-rich and core domains using native p53 as immunogen. Therefore, we decided to produce a truncated p53 recombinant protein corresponding to amino acids 72-308 and to use it as immunogen. Early during the antibody selection, we determined the epitope of six antibodies out of nine by PEPSCAN-ELISA. Three (H53 C4, C8, and C9) recognized the same epitope within the L2 loop of the core domain, an epitope for which several MAbs have been previously described: HO3-5, HO31-1,(19) and DO11.(20) This observation suggests that this portion is more immunogenic than other parts of the p53 core domain, consistent with the external position of this L2 loop determined through crystallography studies. ${ }^{(8)}$

Another antibody, $\mathrm{H} 53 \mathrm{C} 1$, bound an epitope located in the second highly evolutionary conserved domain of p53. Interestingly, not much is known concerning the immunogenicity of

A.

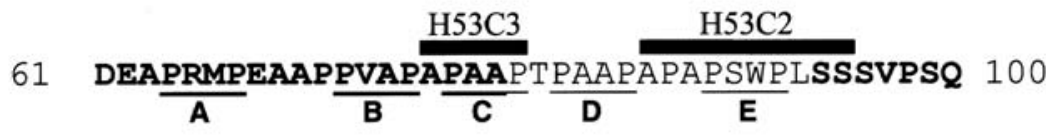

B.

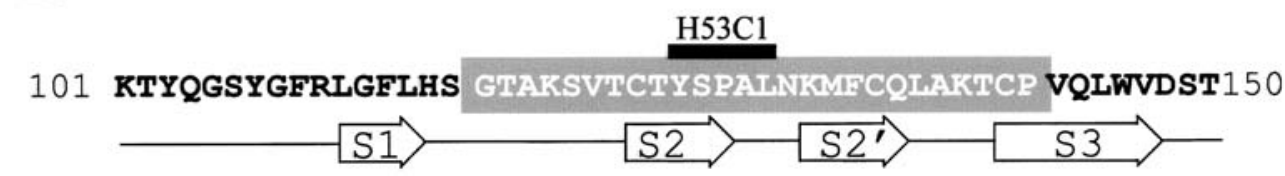

FIG. 1. Localization of the epitopes recognized by $\mathrm{H} 53 \mathrm{C} 1, \mathrm{H} 53 \mathrm{C} 2$, and $\mathrm{H} 53 \mathrm{C} 3$ on p53 amino acid sequence. Black bars, epitope location; underlined sequences, PXXP proline rich motifs $(\mathrm{A}-\mathrm{E})^{(15)}$; plain region, negative regulating domain ${ }^{(12)}$; gray box, second highly conserved region of $\mathrm{p} 53^{(45)} ; \mathrm{S} 1-\mathrm{S} 3$ arrows, sheets deduced from crystallography data. ${ }^{(8)}$ 


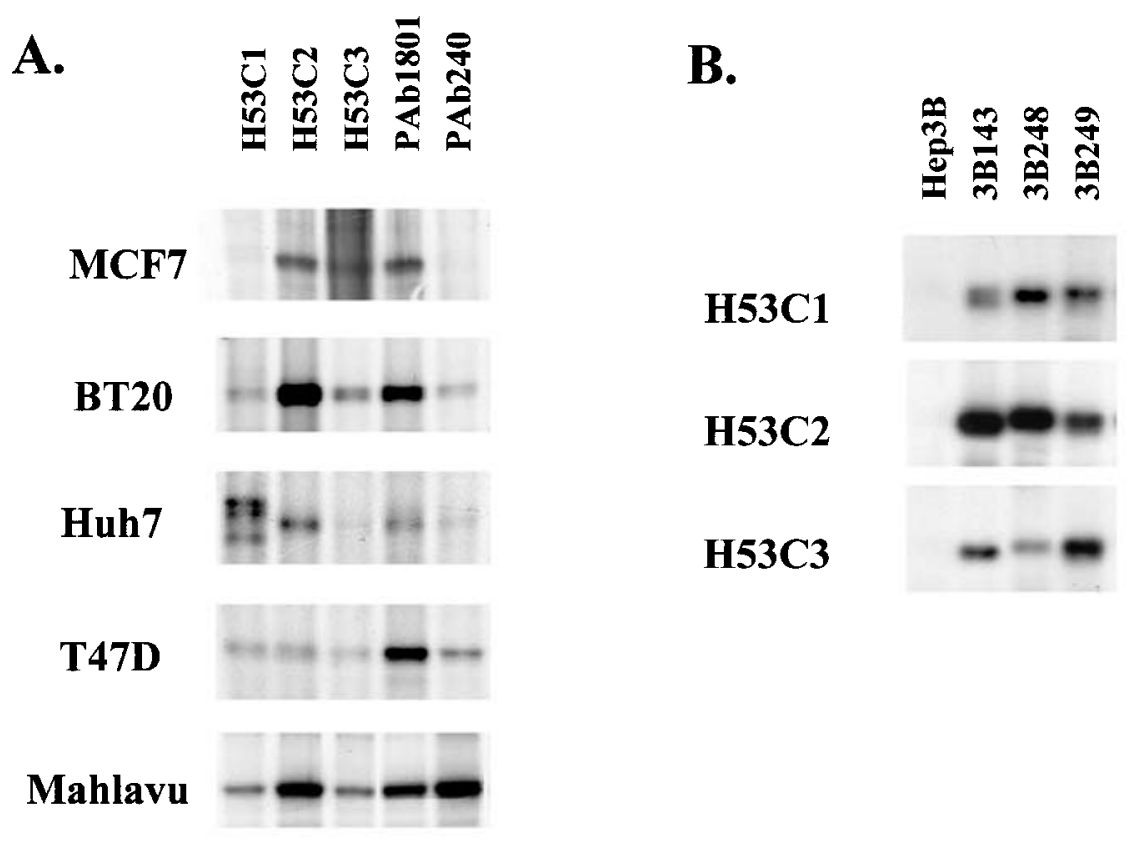

FIG. 2. Immunoprecipitation of wild-type (MCF7) or mutant (BT 20, Huh7, T47D, Mahlavu) endogenous p53 from various tumor cell lines $(\mathbf{A})$ or p53 mutants stably expressed in the p53 null Hep3B cell line (B). For the exact p53 status in cell lines, see Table 2.

this domain, for which no antibody has been described. The analysis of missense mutations pattern observed in human cancer cells reveals that this region is rarely targeted for somatic mutations. However, mutations of this region were associated with a poor prognosis in breast and lung tumors. ${ }^{(28,29)}$ Structurally, this domain corresponds to the Sheet Loop Helix motif that contributes to the folding of the $\mathrm{p} 53$ protein by bringing together distant residues (Lys120 and Arg283) to form a specific DNA-binding motif. ${ }^{(8)}$ This suggests that this region is crucial for the protein conformation. The fact that $\mathrm{H} 53 \mathrm{C} 1$ can distinguish mutant from wild-type p53 confirms the structure data. As this antibody displays a better affinity for mutant p53 proteins, its epitope may not be accessible in the native conformation necessary for DNA-binding. Also, the high degree of conservation suggests that it could bear an unknown specific function of p53. A tool such as $\mathrm{H} 53 \mathrm{C} 1 \mathrm{MAb}$ may help to better understand specific functions of this region.

Until recent studies, no particular function was attributed to the region of $\mathrm{p} 53$ located between the transactivation and the core domains. However, the analyses by enzymatic digestions indicated that a domain between amino acids 68 and 96 was resistant to proteolysis by subtilisin, suggesting that it could play a role in p53 stability. ${ }^{(9)}$ Indeed, in this region, two overlapping domains have been defined to drive different activities. First,

Table 2. Summary of the Immunoreactivity of New Anti-p53 Monoclonal Antibodies with Wild-Type and Mutant P53 Proteins as Tested by Immunoprecipitation after Metabolic Labeling of Different Cell Lines by $\left[{ }^{35}\right.$ S]-Methionine

\begin{tabular}{|c|c|c|c|c|c|c|}
\hline Cell lines & p53 status & $P A b 1801$ & $P A b 240$ & $\mathrm{H} 53 \mathrm{Cl}$ & H53 C2 & $\mathrm{H} 53 \mathrm{C3}$ \\
\hline MCF7 & WT & ++ & - & - & ++ & + \\
\hline HepG2 & WT & ++ & - & - & ++ & + \\
\hline HBL100 & $\mathrm{WT}+\mathrm{TAg}$ & ++ & + & - & ++ & ++ \\
\hline BT20 & K132Q & ++ & + & + & ++ & + \\
\hline T47D & L194F & ++ & + & + & + & + \\
\hline Huh7 & Y220C & ++ & + & - & ++ & + \\
\hline Mahlavu & A249S & ++ & ++ & + & ++ & + \\
\hline Нер3В & Null & - & - & - & - & - \\
\hline 3B143 & V143A & ++ & ++ & + & ++ & ++ \\
\hline 3B248 & R248W & ++ & ++ & + & ++ & + \\
\hline 3B249 & R249S & ND & ND & + & ++ & + \\
\hline
\end{tabular}


Walker and Levine have shown that the proline-rich region which contains several P-X-X-P motifs between residues 63 and 85 (Fig. 1) was involved in the transmission of antiproliferative signals. ${ }^{(15)}$ Secondly, Muller-Tieman et al. have reported that residues $86-93$ could be involved in the negative regulation of specific DNA-binding of p53. ${ }^{(12)}$ Previous studies have suggested that the C-terminal negative regulatory domain (330-393) could inhibit DNA-binding of p53 through an interaction with the core domain. ${ }^{(30-32)}$ Muller-Tieman et al. have determined that amino acids 80-93 were necessary for this interaction and that corresponding synthetic peptides could activate the p53 specific DNA-binding activity. This region may then be involved in the regulation of the p53 conformation and conformation-dependent activities. ${ }^{(12)}$

The proline-rich region is fairly conserved among mammalians, ${ }^{(33)}$ and proline motifs (P-X-X-P) are present at least as one copy in all the referred mammalian $\mathrm{p} 53$ proteins as well as in the p53 homologues p63 and p73 protein (34). We obtained two MAbs recognizing sequences located in this region: $\mathrm{H} 53 \mathrm{C} 2$ and $\mathrm{H} 53 \mathrm{C} 3$. The MAb H53C3 precisely binds the third proline motif (P-A-A-P) of human $\mathrm{p} 53$, five residues upstream the $\mathrm{H} 53 \mathrm{C} 2$ epitope, which encompasses the fifth Proline motif (P-S-W-P) (Fig. 1). These two MAbs may be helpful in studying this proline-rich domain and better defining the relative implication of these two motifs in p53 conformation and activity.

Furthermore, the epitope defined by PEPSCAN analysis for $\mathrm{H} 53 \mathrm{C} 2$ is within a 10 -amino-acid sequence located at the frontier between the proline-rich region described by Walker et al. and the core domain. ${ }^{(15)}$ As shown in Figure 1, this sequence also corresponds to the negative regulatory domain described by Muller-Tiemann et al. ${ }^{(12)}$ The location of this epitope suggests that $\mathrm{H} 53 \mathrm{C} 2$ could help to study the central negative regulatory region of p53 and that it could be able to modulate the DNA-binding activity of p53, as PAb421 does through its binding to the C-terminal negative regulation domain. ${ }^{(13,39)}$

In other respects, it is also worthwhile to point out that the $\mathrm{H} 53 \mathrm{C} 2$ epitope is located near the interaction domain of $\mathrm{p} 53$ with inactive JNK at residues 97-116, while active JNK phosphorylates p53 on threonine 81 , just beside the $\mathrm{H} 53 \mathrm{C} 3$ epitope. ${ }^{(40)}$ These two MAbs could then be very useful for studying JNK-related regulation of $\mathrm{p} 53$.

In conclusion, p53-specific MAbs are used for many purposes, from the characterization of functional or regulatory domains to therapeutic strategies. ${ }^{(41-44)}$ The three MAbs described here $(\mathrm{H} 53 \mathrm{C} 1, \mathrm{H} 53 \mathrm{C} 2$, and $\mathrm{H} 53 \mathrm{C} 3)$ offer new opportunities for such strategies, since they bind new epitopes within regions important for p53 activities. H53C1 could help study mutations affecting the core domain. $\mathrm{H} 53 \mathrm{C} 1$ and $\mathrm{H} 53 \mathrm{C} 2$ may provide additional tools for studying modulation of DNA binding activity. $\mathrm{H} 53 \mathrm{C} 2$ and $\mathrm{H} 53 \mathrm{C} 3$ could be useful in analyzing the regulation by the proline-rich region as well as the JNK interaction and phosphorylation, on the p53 activity.

\section{ACKNOWLEDGMENTS}

This work was supported by grants from INSERM, TUBITAK and TWAS to M. Ozturk. The authors wish to thank P. Hainaut and A. Puisieux for helpful discussions.

\section{REFERENCES}

1. Soussi T, and Beroud C: Assessing TP53 status in human tumours to evaluate clinical outcome. Nat Rev Cancer 2001;2:33-40.

2. el-Deiry WS, Tokino T, Velculescu VE, Levy DB, Parsons R, Trent JM, Lin D, Mercer WE, Kinzler KW, and Vogelstein B: WAF1, a potential mediator of p53 tumor suppression. Cell 1993;75: 817-825.

3. May P, and May E: Twenty years of p53 research: structural and functional aspects of the p53 protein. Oncogene 1999;18: 7621-7636.

4. Oren M. Decision making by $\mathrm{p} 53$ : life, death and cancer. Cell Death Differ. 2003;10:431-442.

5. Manfredi JJ: p53 and apoptosis: it's not just in the nucleus anymore. Mol Cell. 2003;11:552-554.

6. Thut CJ, Chen JL, Klemm R, and Tjian R: p53 transcriptional activation mediated by coactivators TafII40 and TafII60. Science 1995;267:100-104.

7. Lu H, and Levine AJ: Human TAFII 31 protein is a transcriptional coactivator of the p53 protein. Proc Natl Acad Sci USA 1995;92:5154-5158.

8. Cho Y, Gorina S, Jeffrey PD, and Pavletich NP: Crystal structure of a p53 tumor suppressor-DNA complex: understanding tumorigenic mutations. Science 1994;265:346-355.

9. Pavletich NP, Chambers KA, and Pabo CO: The DNA-binding domain of $\mathrm{p} 53$ contains the four conserved regions and the major mutation hot spots. Genes Dev 1993;7:2556-2564.

10. Bargonetti J, Manfredi JJ, Chen X, Marshak DR, and Prives C: A proteolytic fragment from the central region of p53 has marked sequence-specific DNA-binding activity when generated from wildtype but not from oncogenic mutant p53 protein. Genes Dev 1993;7:2565-2574.

11. Clore GM, Omichinski JG, Sakaguchi K, Zambrano N, Sakamoto H, Appella E, and Gronenborn AM: High-resolution structure of the oligomerization domain of $\mathrm{p} 53$ by multidimensional NMR. Science 1994;265:386-391.

12. Muller-Tiemann BF, Halazonetis TD, and Elting JJ: Identification of an additional negative regulatory region for $\mathrm{p} 53$ sequence-specific DNA binding. Proc Natl Acad Sci USA 1998;95:6079-6084.

13. Hupp TR, Meek DW, Midgley CA, and Lane DP: Regulation of the specific DNA binding function of p53. Cell 1992;71:875-886.

14. Halazonetis TD, Davis LJ, and Kandil AN: Wild-type p53 adopts a "mutant"-like conformation when bound to DNA. Embo J 1993;12:1021-1028.

15. Walker KK, and Levine AJ: Identification of a novel p53 functional domain that is necessary for efficient growth suppression. Proc Natl Acad Sci USA 1996;93:15335-15340.

16. Ruaro EM, Collavin L, Del Sal G, Haffner R, Oren M, Levine AJ, and Schneider C: A proline-rich motif in p53 is required for transactivation-independent growth arrest as induced by Gas1. Proc Natl Acad Sci USA 1997;94:4675-4680.

17. Venot C, Maratrat M, Dureuil C, Conseiller E, Bracco L, and Debussche L: The requirement for the $\mathrm{p} 53$ proline-rich functional domain for mediation of apoptosis is correlated with specific PIG3 gene transactivation and with transcriptional repression. EMBO J 1998;17:4668-4679.

18. Gannon JV, Greaves R, Iggo R, and Lane DP: Activating mutations in p53 produce a common conformational effect. A monoclonal antibody specific for the mutant form. EMBO J 1990;9: $1595-1602$.

19. Legros Y, Meyer A, Ory K, and Soussi T: Mutations in p53 produce a common conformational effect that can be detected with a panel of monoclonal antibodies directed toward the central part of the p53 protein. Oncogene 1994;9:3689-3694.

20. Vojtesek B, Dolezalova H, Lauerova L, Svitakova M, Havlis P, Kovarik J, Midgley CA, and Lane DP: Conformational changes in 
p53 analysed using new antibodies to the core DNA binding domain of the protein. Oncogene 1995;10:389-393.

21. Cohen PA, Mani JC, and Lane DP: Characterization of a new intrabody directed against the N-terminal region of human p53. Oncogene 1998;17:2445-2456.

22. Lubin R, Schlichtholz B, Bengoufa D, Zalcman G, Tredaniel J, Hirsch A, de Fromentel CC, Preudhomme C, Fenaux P, Fournier $\mathrm{G}$, et al: Analysis of p53 antibodies in patients with various cancers define B-cell epitopes of human p53: distribution on primary structure and exposure on protein surface. Cancer Res 1993;53: 5872-5876.

23. Ponchel F, Puisieux A, Tabone E, Michot JP, Froschl G, Morel AP, Frebourg T, Fontaniere B, Oberhammer F, and Ozturk M: Hepatocarcinoma-specific mutant p53-249ser induces mitotic activity but has no effect on transforming growth factor beta 1-mediated apoptosis. Cancer Res 1994;54:2064-2068.

24. Voeltzel T, Benard J, Lavaissiere L, Solere P, Da Silva J, Bohuon $\mathrm{C}$, and Bidart JM: Antigenic properties associated with Vinca alkaloid resistance in ovarian cancer cells: identification of a 92,000Da protein. Biochem Biophys Res Commun 1991;180:334-341.

25. Yewdell JW, Gannon JV, and Lane DP: Monoclonal antibody analysis of p53 expression in normal and transformed cells. J Virol 1986;59:444-452.

26. Banks L, Matlashewski G, and Crawford L: Isolation of humanp53-specific monoclonal antibodies and their use in the studies of human p53 expression. Eur J Biochem 1986;159:529-534.

27. Legros $\mathrm{Y}$, Lafon $\mathrm{C}$, and Soussi T: Linear antigenic sites defined by the B-cell response to human p53 are localized predominantly in the amino and carboxy-termini of the protein. Oncogene 1994;9:2071-2076.

28. Bergh J: Time for integration of predictive factors for selection of breast cancer patients who need postoperative radiation therapy? J Natl Cancer Inst 1997;89:605-607.

29. Vega FJ, Iniesta P, Caldes T, Sanchez A, Lopez JA, de Juan C, Diaz-Rubio E, Torres A, Balibrea JL, and Benito M: p53 exon 5 mutations as a prognostic indicator of shortened survival in nonsmall-cell lung cancer. Br J Cancer 1997;76:44-51.

30. Hupp TR, Sparks A, and Lane DP: Small peptides activate the latent sequence-specific DNA binding function of p53. Cell 1995; $83: 237-245$

31. Waterman JL, Shenk JL, and Halazonetis TD: The dihedral symmetry of the p53 tetramerization domain mandates a conformational switch upon DNA binding. EMBO J 1995;14:512-519.

32. Gu W, and Roeder RG: Activation of p53 sequence-specific DNA binding by acetylation of the p53 C-terminal domain. Cell 1997;90:595-606.

33. Soussi T, and May P: Structural aspects of the $\mathrm{p} 53$ protein in relation to gene evolution: a second look. J Mol Biol 1996; 260:623-637.

34. Yang A, Kaghad M, Caput D, and McKeon F: On the shoulders of giants: p63, p73 and the rise of p53. Trends Genet 2002;18 2:90-5.

35. Hainaut $\mathrm{P}$, Hernandez T, Robinson A, Rodriguez-Tome, $\mathrm{P}$, Flores T, Hollstein M, Harris CC, and Montesano R: IARC Database of p53 gene mutations in human tumors and cell lines: updated compilation, revised formats and new visualisation tools. Nucleic Acids Res 1998;26:205-213.

36. Dippold WG, Jay G, DeLeo AB, Khoury G, and Old LJ: p53 transformation-related protein: detection by monoclonal antibody in mouse and human cells. Proc Natl Acad Sci USA 1981;78: $1695-1699$.

37. Lane DP, Stephen CW, Midgley CA, Sparks A, Hupp TR, Daniels DA, Greaves R, Reid A, Vojtesek B, and Picksley SM: Epitope analysis of the murine p53 tumour suppressor protein. Oncogene 1996;12:2461-2466.

38. Wolkowicz R, Elkind NB, Ronen D, and Rotter V: The DNA binding activity of wild type p53 is modulated by blocking its various antigenic epitopes. Oncogene 1995;10:1167-1174.

39. Abarzua P, LoSardo JE, Gubler ML, and Neri A: Microinjection of monoclonal antibody PAb421 into human SW480 colorectal carcinoma cells restores the transcription activation function to mutant p53. Cancer Res 1995;55:3490-3494.

40. Pluquet $\mathrm{O}$, and Hainaut $\mathrm{P}$ : Genotoxic and non-genotoxic pathways of p53 induction. Cancer Lett 2001;174:1-15.

41. Ruiz PJ, Wolkowicz R, Waisman A, Hirschberg DL, Carmi P, Erez N, Garren H, Herkel J, Karpuj M, Steinman L, Rotter V, and Cohen IR: Idiotypic immunization induces immunity to mutated p53 and tumor rejection. Nat Med 1998;4:710-712.

42. Erez-Alon N, Herkel J, Wolkowicz R, Ruiz PJ, Waisman A, Rotter V, and Cohen IR: Immunity to p53 induced by an idiotypic network of anti-p53 antibodies: generation of sequence-specific antiDNA antibodies and protection from tumor metastasis. Cancer Res 1998;58:5447-5452.

43. Caron de Fromentel C, Gruel N, Venot C, Debussche L, Conseiller E, Dureuil C, Teillaud JL, Tocque B, and Bracco L: Restoration of transcriptional activity of p53 mutants in human tumour cells by intracellular expression of anti-p53 single chain Fv fragments. Oncogene 1999;18:551-557.

44. Mary MN, Venot C, Caron de Fromentel C, Debussche L, Conseiller E, Cochet O, Gruel N, Teillaud JL, Schweighoffer F, Tocque B, and Bracco L: A tumor-specific single-chain antibody dependent gene expression system. Oncogene 1999;18:559-564.

45. Soussi T, Caron de Fromentel C, and May P: Structural aspects of the p53 protein in relation to gene evolution. Oncogene 1990;5: 945-952.

Address reprint requests to:

Thibault Voeltzel, Ph.D. INSERM U590

Centre Léon Bérard 28 rue Laënnec

69008 Lyon, France

E-mail: voeltzel@lyon.fnclcc.fr

Received for publication May 6, 2004. Accepted for publication July 1, 2004. 